\title{
PALEOCOLLAPSE STRUCTURES AS GEOLOGICAL RECORD FOR RECONSTRUCTION OF PAST KARST PROCESSES DURING THE UPPER MIOCENE OF MALLORCA ISLAND
}

\author{
P.A. Robledo Ardila, J.J. Durán and L. Pomar
}

\begin{abstract}
Paleocollapse structures and collapse breccias are one of the major features for paleokarst analysis and paleoclimate record. These are affecting the Llucmajor and Santanyí carbonate platforms. These platforms, of southern and eastern Mallorca respectively, are a good example of progradation reef platform in the western Mediterranean. The Santanyí platform is constituted of two sedimentary units, both affected by paleocollapse structures: (1) The Reef Complex attributed to the upper Tortonian-lower Messinian; (2) Santanyí Limestone attributed to the Messinian. There are abundant paleocollapse outcropping in the Reef Complex and Santanyí Limestone units. These structures have been produced by roof collapse of caverns developed in the underlying reefal complex. According to the genetic model, the origin of same paleocollapse structures may be related to early diagenetic processes controlled by high-frequency sea-level fluctuations. During the lowstands of sea level, fresh water flow or mixing zone might have created a cave system near the water table by dissolution of aragonite in the reef front facies and coral patches existing in the lagoonal beds. During subsequent rise and highstands of sea level, inner-shelf beds overlaid the previously karstified reef-core and outer-lagoonal beds. Increase of loading by subsequent accretion of the shallow-water carbonate might have produced paleocollapse structures by gravitational collapse of cave roof. Morphometric and structural classification of paleocollapse is based on geometric and structural criteria according to the type of deformed strata and strata dip. Paleocollapse structures can be classified according to geometric section, size of the paleocave and lithification degree of the host rock when collapsed. Breccias are classified as crackle, mosaic and chaotic types. In same paleocollapse the type of breccias present a vertical and lateral gradation, from crackle in the upper part, to chaotic in the lower part of the paleocollapse. Chaotic breccias grade from matrix-free, clasts-supported breccias to matrix-supported breccias. Relationship with high frequency of sea-level fluctuation, facies architecture, classification features and products permit to enhance a general paleoclimatic framework
\end{abstract}

Key words: Breccias, paleoclimate, paleocollapse, paleocave, Upper Miocene.

\section{Introduction}

The Balearic Islands (Mallorca, Menorca, Ibiza, Formentera and others small islands) are the emerged part of the Balearic Promontory. Mallorca Island can be divided in several morphotectonic units of which one is object of analysis: Llucmajor and Santanyí plat- 
forms in the south and east coast of Mallorca island (figure 1). These are carbonate platforms composed of a Reef Complex (Pomar, 1991; Pomar, 1993 Pomar et al., 1996) and shallow water carbonate complex (Santanyí Limestones Unit) (Fornós, 1983; Fornós, 1989; Fornós and Pomar 1983 a, b and c; Fornós and Pomar 1984; Fornós and Pomar, 1986).

From Upper Miocene tectonics and geomorphologic processes have configured the coastal line on Llucmajor and Santanyí platforms. The karst phenomena has been one of the more intensive processes affecting the rock. There are several features related with the karst, such as fossil collapse structures (Esteban and Clappa, 1983; Fornós, 1988; Robledo and Pomar, 2000; Robledo, 2001). These features outcrop greatly in the sea cliff of the Llucmajor and Santanyí platforms. In Cabo Blanco, Punta Negra, Cala Figuera, Punta des Savinar, Porto-Colom and Cala Murta localities the paleocollapse outcrop exquisitely.

Paleocollapse structures affecting Miocene carbonate rock of Mallorca Island are a consequence of a geological complex history. Spatial complexities, both lateral and vertical, are conditioned for high-frequency of sea-level fluctuations during the Upper Miocene (Robledo and Pomar, 2000; Robledo, 2001). Eustatics changes controlled the facies architecture, base level, water table and subaerial exposure time of the rock, giving place to epigenic dissolution processes and diagenesis. To define paleocollapse geometry, scale, and spatial complexities for analysis, their epigenic histories, mineralogy (James and Choquette 1988; Bosak et al. 1989; Saller et al., 1994) and sin-sedimentary modifications related to sea-level fluctuations should be understood. Uplift could induce fracturing and faulting as further control of karst development.

Previously studied major paleocollapse systems are described in the literature as nearsurface dissolution processes forms, that are not physically related in time or space to the active karst processes (Loucks, 1999; Baceta et al., 2001). Paleokarst associated with mixing zone is considered as complex system due to the intensive changes in porosity and diagenesis (Saller et al., 1994).

The geological model we expose, will show that the high frequency sea-level fluctuation controlled the progradation and agradation of the reef and consequently the reefal lagoonal deposit formation. In the lagoon deposit there are a coral patches, with lateral heterogeneous distribution. Aragonite is a predominant mineral in these structures. Irregular distribution of lithology in lagoonal beds, as well as the water table or/and fresh and salt water in the mixing zone fluctuation, could determine the irregular dissolution distribution in the carbonate platforms.

Paleokarst collapse structures data are limited to 2-D outcrops. Collapse phenomena can give place to different types of breakdown and breccias that commonly characterize several paleocollapse structures providing information about the processes affecting these. Objectives of this paper are: (1) to relate the high-frequency sea-level fluctuation with paleocollapse structures attending to the facies architecture pattern and near-surface processes during the Upper Miocene in the carbonate platforms; (2) to interprete the genetic model of paleocollapse structures distribution related with paleoclimate record;

(3) to describe features and products resulted from the collapse phenomena. 


\section{Geologic setting}

Carbonate rocks of the Upper Miocene outcrop along the coastal cliffs of Mallorca, enabling a detailed study of the facies architecture, of its diagenetic evolution and of associated processes. In the Balearic archipelago (Mallorca, Menorca, Ibiza, Formentera and other smaller islands) these rocks are post-orogenic and overlie the deformed Early and Middle Miocene, Palaeogene and Mesozoic. These deposits correspond to tabular, calcareous- dolomitic shelves presenting with both normal and slip-strike faults, as well as with slight tilting which occurred during the Upper Neogene to Middle Pleistocene (figure 1). Llucamajor Platform has a thickness of $90 \mathrm{~m}$ and an extension of $20 \mathrm{~km}$ (Pomar et al., 1996). Santanyí Platform has a thickness of $30 \mathrm{~m}$ and an extension of 70 km. The Reef Complex and Santanyí Limestone are separate by erosion surface (Fornós, 1989).

Upper Tortonian and Messinian carbonates consist of reefal complexes that prograded across platforms surrounding paleoislands. These carbonate build-ups consisted of shelfmargin tracts of coral reefs with fore-reef slopes and back-reef lagoons. Progradation of these reef systems produced a fairly simple vertical sequence of lithofacies. The openshelf (shallow-basin) lithofacies is overlaid by fore-reef-slope. The reef front lies over this unit and the lagoon lithofacies is the top of the sequence. Complexities on the strata patterns and facies architecture of these reefal platforms resulted from changes on carbonate production and accommodation related to high-frequency sea-level fluctuations (Pomar, 2001).

On the Eastern coast of Mallorca, the reefal complex is overlain by a Messinian shallowwater carbonate complex, (the Santanyí Limestone), which consists of thin-to mediumbedded grainstones, packstone and wackestones-mudstones. Packstone and grainstone appear with vertical root traces (mangrove swamps), stromatolitic bindstones and mudstones, and cross-bedded oolitic grainstone (Fornós, 1989).

Paleocollapse structures outcrop mainly in the Santanyí Platform (figure 1).

\section{Geological models as a tool for reconstruction of the paleoclimatic record during the upper Miocene}

One major mechanism to produce secondary porosity in subsurface carbonates rocks is near-surface dissolution processes associated to coastal marine karst (Saller et al., 1994; Mylroie and Carew, 1995). Epigenic cave systems are the most common type of marine coastal karst in heat-wet regions, sometimes causing collapse of the upper layers (Hanshaw and Back, 1980; Back et al., 1986; Back, 1992; Baceta et al., 2001).

Pomar (2001 a and b), noted from paleoclimatic curve, that the conditions in the MiddleUpper Miocene in Mallorca Island correspond to subtropical/tropical climate according to the builds-up of the Lower Tortonian rhodalgal/foramol ramp and the Upper Tortonian-Lower Messinian reefal platform. According to the geologic pattern described by Pomar (1991 and 1993); Pomar et al., (1996); Pomar and Ward (1999) and Pomar (2001 $\mathrm{a}$ and $\mathrm{b}$ ) by the carbonate platform, sea-level fluctuation supported a high frequency during the Middle and Late Tortonian and Messinian enhanced until 7th order-cycles. As a consequence of this, the water table, controlled by the base level, fluctuated several times, producing also the fluctuation of the phreatic (mixing zone?) or the vadose zone. Fluctuation of vadose and phreatic dominium during the Upper Miocene, lead to differ- 




Figure 1. Geological and Geographical setting. (A) Carbonate platforms of the Upper Miocene in Mallorca and (B) in the Balearics Islands. The figure $\mathrm{C}$ show the reefal outcrop attributed to he Upper Miocene and its north limit surrounding the Occidental Mediterranean.

ential rock dissolution as different mineralogy and fracturation distribution existed. According to this, Pomar et al., (1996); Pomar, (1999) described the heterogenic distribution on calcite, dolomite and aragonite in the Reef Complex. Giménez et al., (2001) hypothesise a possible fracturing during the Upper Miocene from tensional stress driven by faults (still moving) affecting the basement or the continental platform.

In the literature, morphology of cave passages in the phreatic or mixings zones is described as chaotic distribution passages with sponge-work, swiss-cheese and buggy porosity of the rock (Ford and Williams, 1996; Palmer, 1995). Below the water table, phreatic passages form a series of elliptical or round chambers linked by short passages often complex in shape (Guillison, 1996). In the Reef Complex of Mallorca, this aspect is conditioned by the exposure time of the coral patches in the nearest continental of the mixing zone or fresh water, developing chambers apparently without links. This fact, confirms that the dissolution of the coral patches was very quick.

\section{Cave collapse phenomena}

Mechanical processes of cave collapse are an important part of cave evolution features and systems to understand the paleocollapse structures. General setting of collapse phenomena as cave ceilings and walls under stress from the weight of overlaying strata (Davis, 1949). A tension dome, or zone of maximum stress, is induced by the presence of a cavity. Stress is relised by collapse of the rock mass within the stress zone. The result is a breakout dome. Breakout domes commonly form in the vadose zone when the water table has fallen leaving the cave (White and White, 1969; White, 1988; Loucks, 1999). 
The collapse can occur in others setting depending if took place in phreatic, vadose or submarine conditions. In this respect, the analysis of the sedimentary special characteristics in the carbonate platform and the products resulting from the collapse phenomena can help us to know the geological aspects associated to collapse process.

\section{Genetic model of the paleocollapse structure}

Cave, collapse, burial-compaction and diagenesis evolution are normally described as processes of different stages (see McCaleb and Wayhan, 1969; Rogers and Davis, 1977; Ohle; 1985; Sando, 1988; Bosak, 1989 Mazzulo and Mazzulo, 1992; Loucks and Handford, 1992; Loucks and Mescher, 1996 Loucks, 1999). Paleocollapse structures are not related to general setting where dissolution takes place in the beginning, developing cave systems, followed by collapse of ceiling or walls and latter burial-compaction and diagenesis. In the paleocollapse structures of Mallorca we have differentiated two stages: 1) fall and low stands of sea-level related to dissolution processes; 2) rise and high stand of sea-level related to collapse and burial-compactation.

Recent unpublished work on the reefal complex cropping out on the southern Mallorca sea cliffs allow to create a genetic hypothesis to explain the origin of similar paleocollapse structures developed in the back-reef lagoonal beds. According to this working hypothesis, the origin of these karst collapse structures may be related to early diagenetic processes controlled by high-frequency sea-level fluctuations, the same sea-level fluctuations that control the facies architecture of the carbonate platforms (Robledo and Pomar, 2000; Robledo, 2001).

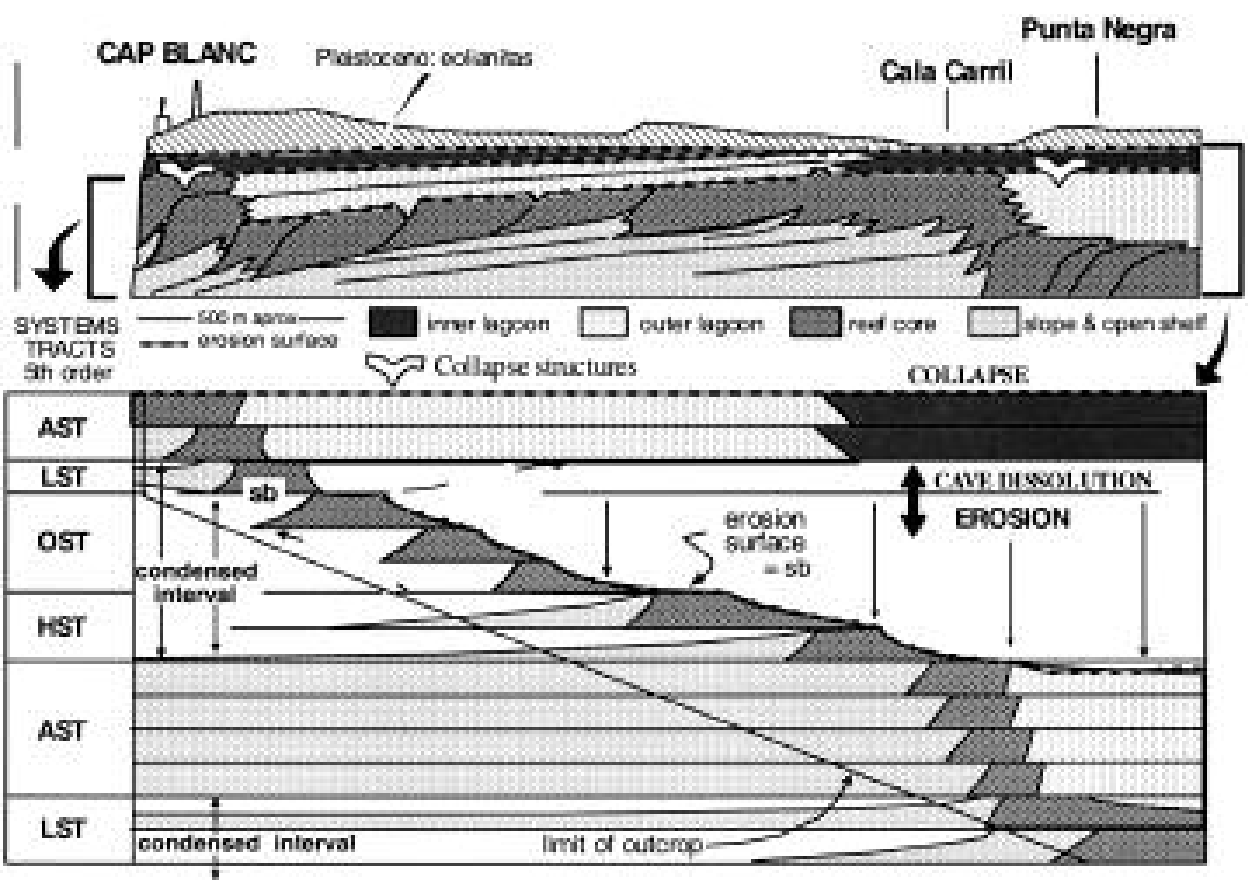

Figure 2. Weeler diagram 


\section{Facies architecture}

Accretional units, within the reefal platform, represent high-frequency depositional sequences formed in response to high-frequency sea-level fluctuations. Up to four bundles (or systems tracts), which are related to specific parts of the sea-level cycle, can be defined from characteristic changes in the hierarchical stacking patterns among these accretional units.

The "lowstand" systems tract (LST) formed during the initial sea-level rise, after the lowest point of the sea-level cycle. It mainly consists of prograding reef-core, with thin forereef-slope and open-shelf lithofacies without significant lagoonal beds.

The aggrading systems tract (AST) corresponds to the most rapidly rising part of the sealevel curve, and it is volumetrically the most important. The AST is characterized by well-developed barrier reefs and thick aggradation without backstepping in all depositional systems, from the lagoon to the open shelf (shallow basin). The AST lagoonal lithofacies overlies the LST and consists of landward onlapping strata.

The highstand systems tract (HST) is related to the highest part of sea-level cycle. It consists of prograding reef core, with forereef-slope lithofacies wedging out basinward and volumetrically condensed open-shelf lithofacies. Lagoonal beds commonly are absent (because of non-deposition or erosion during subsequent fall of sea level). The offlapping systems tract (OST) formed during falling sea level. It consists of prograding and downstepping reef lithofacies (fringing reefs without significant forereef-slope lithofacies), which downlaps on to the distal-slope and open-shelf lithofacies of the previous HST. There is no lagoonal lithofacies, and the open-shelf lithofacies is volumetrically condensed.

\section{Paleocollapse structures genesis}

During lowstands and fall of sea level (figure 3) fresh-water flow or mixing zone might have created a cave system near the water table by dissolution of aragonite (mainly corals) in the reef front facies and coral patches existing in the lagoonal beds (just behind the reef tract) of the previous AST (figure 2). This cave system developed near the subaerial erosion surface. During subsequent rise of sea level and sea level high, inner lagoonal beds overlaid the previously karstified reef-core and outer-lagoonal beds. Increase of loading by subsequent accretion of the lagoonal beds might have produced paleocollapse structures by gravitational collapse of cave roofs when these beds were still not completely consolidated. (figure 3 )

According to this hypothetical model, these collapse structures will preferentially occur in the reef core and back-reef settings of the aggrading systems tracts. It is worth to mention that this structure occurs in similar setting, at top of an aggrading segment of the platform. Even though, much of the lithologic complexity of these platforms is beyond the resolution of current subsurface methods, the causal relationship between depositional and early diagenetic processes here hypothesized, is relevant to predicting and analysing the heterogeneous distribution of rock properties in reef-complex reservoirs.

\section{Paleocollapse feature and products Geometry and forms of the paleocollapse}

The section study of the results forms in the palecollapse structure is based in a morphometric analysis according the size and geometry of them. The Paleocollapse typo present three different parts: 1) paleocave in the base of the structure (always in the reef front of 

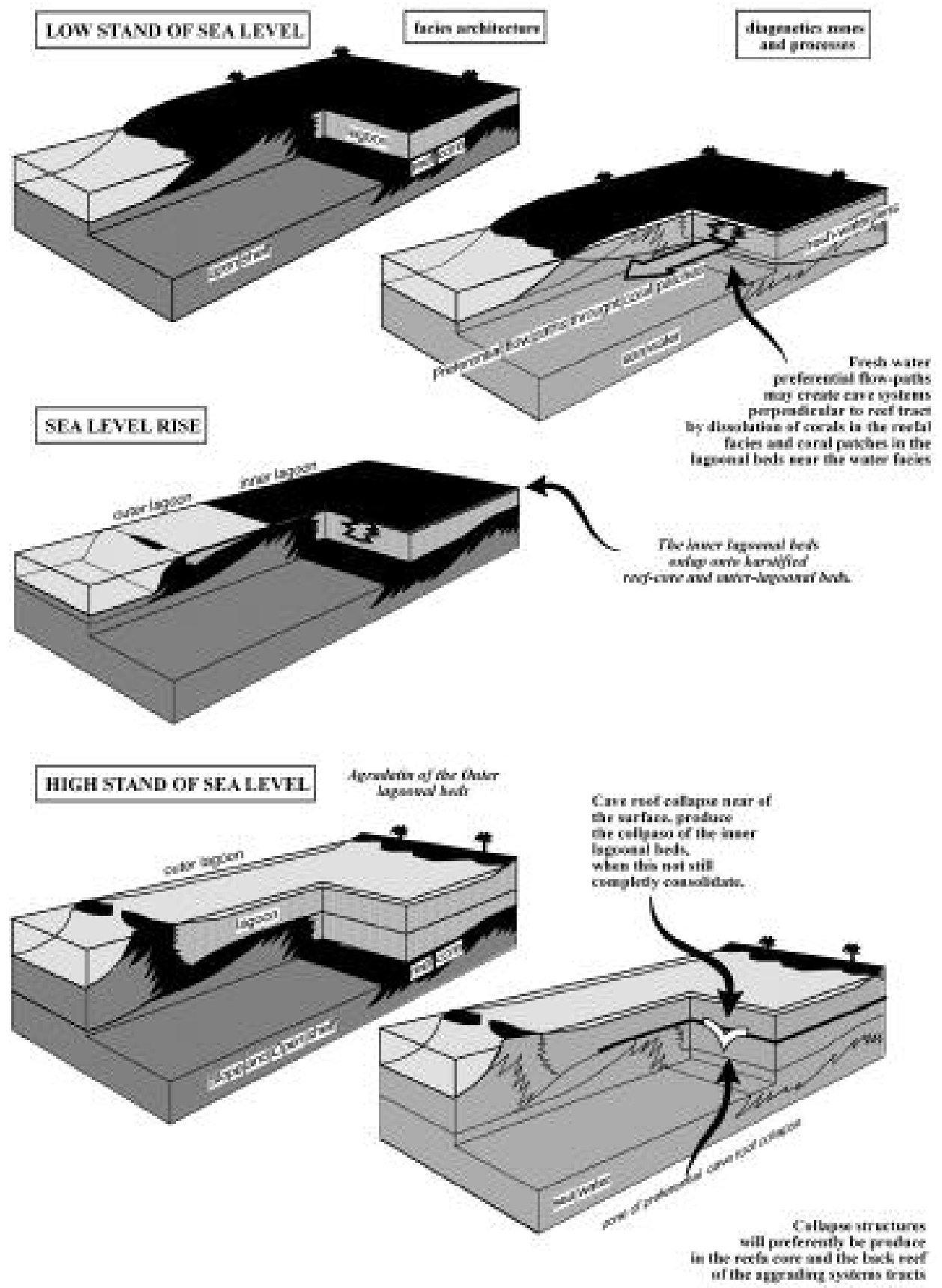

Figure 3. Genetic model of paleocollapse structures 
lagoonal facies; 2) vertical passage in the middle part; 3) deformed beds in the upper part (figure 4). Both, middle and upper part can locate in the Reef Complex or Santanyí Limestone. Have been taken as data:

High: vertically from the upper part of the Santanyí Limestone (in Santanyí Platform) or inner lagoon (in Llucmajor Platform), to the lower part outcropping in the lagoonal facies and/or reef front in the Reef Complex (figure 4)

Wide: laterally from the beginning of the deformation of the beds collapsed in both vertex of the paleocollapse (figure 4)

We can describe the outcrops of paleocollapse in section from a geometric and morphosedimentary criteria. The numerous outcrop of structures permit observe several forms. Have been located a lot of group of structures without a clear geometry. However, we have differenced several paleocollapses outcropping with a geometry section. Predominate the forms of funnel (figure 4), $\mathbf{V}$ or $\mathbf{U}$ structures (figure 6) (in section) where the overlayers dipping towards the paleocave (figure 4 and 5).

In this order, the size of the paleocollapse is the second parameter to describe 2D outcrop features. 263 paleocollapse structures observed the size fluctuate from $35 \mathrm{~m}$ of high and $30 \mathrm{~m}$ of wide to centimetric structures. Moreover, in section we can observe fracturation levels decreasing in size (meters to centimetres) and dip $\left(30^{\circ}\right.$ to $\left.90^{\circ}\right)$ from the centre of the paleocollapse (paleocave) to the vertexes of them consequence of shear stress. Fractures and dip directions rotate within the paleocollapse structure and within the paleocave on a larger scale. The locals fracture levels are common in the beds collapsed. Is predominant the extensional fracture with size from several meters to centimetres. The beds fracturated, when these collapsed, generated symmetric and asymmetric or fractured and faulted paleocollapse structures.

In this order, we can classify the paleocollapse structure of Mallorca Island in two principals categories: sin-sedimentary and post-sedimentary structures (figure 6).

Figure 4.- Paleocollapse structure type. Points where data have been taken. Type and gradation of the breccias

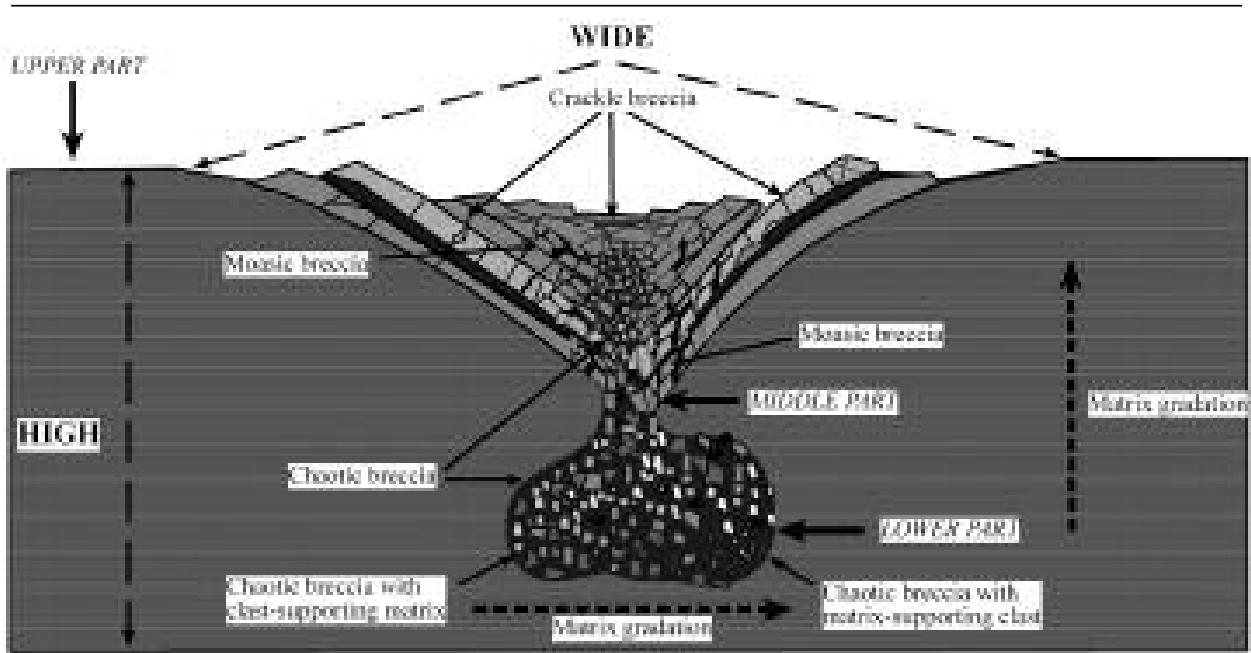






Figure 5.- Paleocollapse structure in Cala Savinar, Santanyí, Mallorca

a) Sin-sedimentary structures: the rocks were not consolidated during the collapse. Then, the weight of the beds and the cavity size needed to deformation is lesser than to consolidate strata. Increasing the cavity size or overlayers weight, the deformation will be bigger (figure 6).

b) Post-sedimentary structures: the rocks were consolidated during the collapse and the weight of the overlayers is very regular in the carbonate platforms. The geometry and structure of this paleocollapse is only controlled for the size of the cavity (figure 6).

In both types, if the same paleocollapse has been affected by tectonic processes it could change the geometry and structure. Rebrecciated chaotic breakdown breccia is a common feature when this has taken place.

The criteria used to make the classification are three: geometric, structural and genetic (explanation in figure 6).

\section{Collapse breccias: types and distribution}

Major products of paleocollapse are chaotic breakdown breccia. Davies (1949) and White and White (1969) defined several types of blocks by different thick and bedded. Loucks and Handford, (1992) and Loucks (1999) present a classification breccia by sev- 
eral large void observed and variables amounts of matrix between angular clasts. According to this classification they define as: (1) crackle breccia when the rock is highly fractured with thin fractures separating breccia clasts; (2) mosaic breccia when displacement between clasts is greater and some of them have rotated. This type can support free-matrix or matrix-rich; (3) chaotic breccia characterized by extensive rotation and displacement of clasts derived from different upper beds and producing polymictic breccia. Chaotic breccia has continuous gradation from matrix-free, clasts-supported breccia and matrix-supported breccia. Cave sediment filling passages can be dominant in some place with mixture or grading sediment types. Collapse breccias in paleocollapse structures of the east coast of Mallorca Island has different compositional characteristics depending on the genetic evolution collapse phenomena from the Upper Miocene. In same cases, they show a vertical gradation between chaotic (in the paleocave), mosaic and crackle breccia (in the upper beds and vertex of the structures). In the paleocollapse base chaotic breccia with great rotation and displacement of clasts is always present (figure 4). The size of the clast range from millimetres to $40 \mathrm{~cm}$ and is composed essentially by a mangrove fragments. Matrix breccia is present in majority of the cases being clast-supported chaotic-breccia more common. The matrix is composed of small limestone clast and/or reddish fine-grained calcareous from the upper layers and host rock. Detritus sediment filling the porosity intra-inter clast is a mixing between calcareous sediments of the host rock, chemical precipitation deposits and clay from the upper facies or sediment infiltrated from the surface in the cave system. 
Usually the mosaic breccias overlay the chaotic breakdown breccias (figure 4). These are composed of clast from the stromatolitic and oolitic facies. The size of them range from centimetres to several meters. Interbreccia matrix not is present. The upper parts of the brecciated zones are formed of crackle and/or mosaic breccia. A continuous gradation occurs between crackle and mosaic breccia depending on the size of the cavity. Crackle breccia are highly fractured rocks with fracture separating breccia clast.

This general arrangement is not always regular and clearly visible. Some examples show vertical alternations of fractured and brecciated zones, others have a more random arrangement.

\section{Discussion}

The paleocollapse structures of Mallorca Island constitute in general one of the better examples because of the good outcrop in sea cliffs. The analysis of these permit to establish a genetic model to explain the genesis, consequence of the high frequency of sealevel fluctuations, the same that controlled the facies architecture. According to the genetic model, the collapses of the cave were produced due to the accretion of the shallow-water carbonate complex (Santanyí Limestone). The genetics and temporal characteristics are given for several types of forms. This fact can help us to make a first classification according to their geometry, structural and genetic occurrence. The analysis of the spatial distribution of the paleocollapse structures show the strong relation with depositional model and facies architecture, facies distribution of the Reef Complex, aragonite coral patches distribution and dissolution of them. However evidences that other elements could related in the actual distribution and develop of this type of structures have not been found. Therefore it would be interesting to open new research lines on the role of the mixing zone or fresh water in the dissolution or the fluctuations of the hydrogeological zone associated to the sea-level.

\section{Conclusions}

The sea-level fluctuations controlled the facies architecture, as well as the water table or mixing zone situation. These oscillations give place to phases of phreatic dominium and subaerial exposure of the rock.

The paleocollapse distribution is heterogeneous and is related to the distribution of the facies architecture and coral patches.

The fall and low stand of sea-level are associated to the coral patches dissolution. The rise and high stand of sea-level are related to the collapse of the cave floors.

The cave collapse give place to several section form, controlled by the size and form of the cave. Funnel, $\mathbf{V}$ and $\mathbf{U}$ geometry section structures have been classified. However, much of them show chaotic forms.

The collapse gives place to the breccia formation. In same examples, these show a grade of typology from the paleocave to the top of the paleocollapse.

The breccias composition is very complex. Normally, matrix-interclast are composed of detritus sediments (clays). In other examples the interclast-breccia porosity is infilled by chemical carbonate sediment.

High frequency of sea-level fluctuation, facies architecture, lithology and dissolution and collapse processes took place below a heat-wet climate. 


\section{Acknowledgements}

The author would like to thank the Geological Survey of Spain for help and logistic assistance. The work was supported by the Research Project DGI n. BTE2001 - 0372-C02 (Spain) and 448 GTE of the PICG (UNESCO).

\section{References}

Back W., 1992 - Coastal karst formed by ground-water discharge, Yucatan, México. International Contributions to Hydrology 13: 461-466.

Back W., Hanshaw B.B., Herman J.S., Van Driel J.N., 1986 - Differential dissolution of Pleistocene reef in the ground-water mixing zone of coastal Yucatan, México. Geology 14(2): 137-140.

Bögli A., 1980 - Karst hydrology and physical speleology. Springer-Verlag, Berlin Heidelberg, New York. 285 p.

Bosak P., Ford D.C., Glazek J., Hóracek I., 1989 - Paleokarst. A systematic and regional review. Amsterdam. Elsevier. Amsterdam. 725 p.

Davis W.E., 1949 - Features of caves breakdown. National Speleological Society Bulletin. 11: 34-35.

Esteban M., Klappa C., 1983 - Subaerial Exposure. In: Sholle P. A., Bebut D. G. \& Moore C. H. (Eds): Carbonate Depositional Environments, American Association of Petroleum Geologists, Tulsa, Oklahoma, USA: 1-96

Fornós J., Pomar L., 1983 - El complejo de manglar del Mioceno terminal de la isla de Mallorca. Bulletí de la Societat d'Història Natural de les Illes Balears 26 : 207-228.

Fornós J., Pomar L., 1983 - Mioceno superior de Mallorca: unidad Calizas de Santanyí (Complejo Terminal). In: El Terciario de las Baleares (Mallorca-Menorca). Guía de excursiones, 10th Congreso Nacional de Sedimentología. Menorca. Universidad de Palma de Mallorca: 177-206.

Fornós J., 1983 - Estudi Sedimentològic del Miocé Terminal de l'illa de Mallorca. Tesina, (Inédita). Universitat de les Illes Balears. Palma de Mallorca. 228 p.

Fornós J., Pomar L., 1984 - Facies, ambientes y secuencias de plataforma carbonatada somera (Formación de Calizas de Santanyí), en el Mioceno Terminal de Mallorca (Islas Baleares). Publicaciones de Geología. 20: 319-330.

Fornós J., 1987 - Les Plataformes Carbonatades de les Balears. Estudi Sedimentològic de les plataformes miocenes de les Illes Balears i la comparació amb la sedimentació actual a la seva plataforma. Tesis Doctoral, (Inédita). Universitat de les Illes Balears. Palma de Mallorca. 954 p.

Fornós J. J., Ginés A., Ginés J., Pomar L., 1988 - Paleokarst collapse breccias in the uppermost Miocene of Mallorca Islands, Spain. 9th IAS Regional Meeting of Sedimentology, Leuven, Belgium, Abstract.

Fornós. J., 1998 - Karst collapse phenomena in the Upper Miocene of Mallorca (Balearic Islands, Western Mediterranean). Acta Geologica Hungarica, 42: 2.

Fornós J.J., Ginés A., Ginés J., Rodriguez, A., 1995 - El Paleokarst a Mallorca. International Symposium on karren landforms. Mallorca, Endins (special bulletin), 20: 113-124.

Ford D.C., Williams P.W., 1989 - Karst geomorphology and hydrology: London, Unwin Hyman, 601 p.

Giménez J., Fornós J., Gelabert B., 2001 - Análisis de la fracturación de los materiales calcáreos neógenos de la costa sudoriental de Mallorca. Geogaceta, 31: 46-49.

Gillieson D., 1996 - Caves; Processes, development, management. Oxford, Basil Blackwell. 324 p.

Hanshaw B.B., Back W., 1980 - Chemical mass wasting of the northern Yucatan peninsula by groundwater dissolution. Geology, 8: 222-358.

James N. P., Choquette P.W., 1988 - Paleokarst. Springer-Verlag. New York. 601 p.

Loucks R.G., Handford C.R., 1992 - Origin and recognition of fractures, breccias and sediments fills in paleocave-reservoir networks. In: Candelaria M.P., Reed C.L. (Eds.): Paleokarst, karst related diagenesis and reservoir development: examples from Ordovician-Devonian age strata of west Texas and the mid-continent. Permian Basin Section. SEMP Publication. 92-33: 31-44. 
Loucks R.G., Mescher P.K., 1996 - Architecture of collapsed-paleocave reservoir. 1996 AAPG Annual Convention Official Program, abstract A87.

Loucks R.G., 1999 - Paleocave Carbonate Reservoir: Origins, burial-depth modifications, spatial complexity and reservoir implication. AAPPG Bulletin, 83: 1795-1834.

MacCaleb J.A., Wayhan D.A., 1969 - Geologic reservoir analysis, Mississippian Madison Formation, Elk basin field, Wyoming-Montana. AAPG Bulletin, 64: 381-389.

Matthews R.K., Frohlich C., 1987 - Forward modelling of bank-margin carbonate diagénesis. Geology, 15: 673-676.

Mazzulo S.J., Mazzulo L.J., 1992 - Paleokarst and karst associated hydrocarbon reservoir in the Fusselman Formation, west Texas, Permian basin. In: Candelaria M.P., Reed C.L. (Eds.): Paleokarst, karst related diagenesis and reservoir development: examples from Ordovician-Devonian age strata of west Texas and the mid-continent : Permian Basin Section, SEMP Publication, 92-33: 110-120.

Mylroie J.E., Carew J.L., 1995 - Karst development on carbonate islands. In: Budd D.A., Saller A.H., Harris P.M. (Eds.): Unconformities and porosity in carbonate strata. AAPG Memoir, 63: 55-76.

Novo P., Chicarro F., 1949 - Diccionario de voces usadas en Geografía física. Real Sociedad Geográfica, Madrid. 409 p.

Ohle E.L., 1985 - Breccias in Mississippi Valley-type deposits. Economic Geology, 80: 1736-1752.

Palmer A.N., 1995 - Geochemical models for the origin of macroscopic solution porosity in carbonate rocks. In: Budd D.A., Saller A.H., and Harris P.M. (Eds.): Unconformities and porosity in carbonate strata. AAPG Memoir, 63: 72-99.

Pomar L., 1993 - High-resolution Sequence Stratigraphy in Prograding Carbonates: Application to Seismic Interpretation. In Loucks B. and Sarg R. J. (Eds.): Carbonate Sequence Stratigraphy: Recent Advances and Applications. A.A.P.G. Memoir, 57, 545 p.

Pomar L., Ward W. C., Green D.G., 1996 - Upper Miocene Reef Complex of the Llucmajor area, Mallorca, Spain. In: Franseen E., Esteban M., Ward W.C., Rouchy J.M. (Eds.): Models for Carbonate Stratigraphy from Miocene Reef Complexes of the Mediterranean regions, SEPM Concepts in Sedimentology and Paleontology Series, 5: 191-225

Pomar L., Ward W. C., 1999 - Reservoir-Scale Heterogeneity in Depositional Packages and Diagenetic Patterns on a Reef-Rimmed Platform, Upper Miocene, Mallorca, Spain. AAPG Bulletin, 83: 1759-1773.

Pomar L., 2001 - Types of carbonate platform: a genetic approach. Basin Research, 13: 313-334.

Pomar L., 2001 - Ecological control of sedimentary accommodation: evolution from a carbonate ramp to rimmed shelf, Upper Miocene, Balearic Island. Palaeogeography, Palaeoclimatoloy, Palaeoecology, 175: 249-272.

Rogers R.K., Davis J.H., 1977 - Geology of the Buick mine Viburnum trend, southeast Missouri. Economic Geology, 72: 372-380.

Robledo P.A., Pomar L., 2000 - Upper Miocene karst collapse structures of the east coast, Mallorca, Spain. Acta Carsologica, 29: 2-12.

Robledo P.A., 2001 - El paleokarst del Mioceno superior del Levante de Mallorca. Memoria de Investigación, (Inédita). Universidad de las Islas Baleares. Palma de Mallorca: 128 p.

Shaller A.H., Budd D.A., Harris P.M., 1994 - Unconformities and Porosity development in carbonate strata: Ideas from a Hedberg Conference. AAPG Bulletin, 78: 857-872.

Sando W.J., 1988 - Madison Limestone (Mississippian) paleokarst: a geologic synthesis. In: James N.P. and Choquette P.W. (Eds.): Paleokarst. Berlin, Springer-Verlag: 256-277.

White E.L., White W.B., 1969 - Processes of cavern breakdown. National Speleothem Society Bulletin, 30: $115-129$.

White W.B., 1988 - Geomorphology and hydrology of karst terrains. New York, University Press, 464 p. 